\title{
The New Great Game: Rivalry of Geostrategies and Geoeconomies in Central Asia
}

\author{
Petar Kurečić
}

The paper studies rivalry of geostrategies and geoeconomies in Central Asia and the Caspian Sea region. These regions have strategic value, particularly considering oil and gas reserves, which also represent a peril to the regional security. After centuries of Russian dominance, Central Asia became a region with five independent states. The Russian influence declined in the 1990s, only to return gradually, but its rivals have shown up. The USA and China started a quest for Central Asian and Caspian Sea oil and gas. The US presence in Iraq, the US and NATO's presence in Afghanistan, US military bases, Russian presence and military bases, China's rising influence, Iran's and Turkey's proximity to the region, and military and economic alliances, show that Central Asia is an arena of great power rivalry. The balance of power, instability and struggle for control over oil and gas reserves mean that the new Great Game has started.

Key words: oil, natural gas, geoeconomy, geostrategy, Caspian Sea, Central Asia

\section{Nova velika igra: suprotstavljenost geostrategija i geoekonomija u Središnjoj Aziji}

Rad istražuje suprotstavljenost geostrategija i geoekonomija u Središnjoj Aziji i regiji Kaspijskog jezera. Regije imaju stratešku važnost kad su posrijedi zalihe nafte i plina, koje predstavljaju i ugrozu regionalnoj sigurnosti. Nakon stoljeća ruske dominacije Središnja Azija postala je regijom s pet neovisnih država. Ruski je utjecaj u devedesetima oslabio; postupno se vratio, no dobio je suparnike. SAD i NR Kina počeli su natjecanje za zalihe nafte i plina u Središnjoj Aziji i regiji Kaspijskog jezera. Prisutnost SAD-a u Iraku i Afganistanu, vojne baze SAD-a, ruska prisutnost i vojne baze, rastući utjecaj Kine, blizina Irana i Turske regiji te vojna i ekonomska savezništva pokazuju da je Središnja Azija predmet suparništva velikih sila. Ravnoteža snaga, nestabilnost i borba za kontrolu nad zalihama nafte i plina znače da je počela nova ,velika igra”.

Ključne riječi: nafta, zemni plin, geoekonomija, geostrategija, Kaspijsko jezero, Središnja Azija 


\section{INTRODUCTION}

The paper studies the rivalry of geostrategies and geoeconomies in the Central Asia and the Caspian Sea region, as well as the main patterns of current strategic and economic relations in these areas. It does not have the ambition to study the overall complexity of contemporary strategic and economic relations in Central Asia, but only to identify the main characteristics of these relations, and the most important players and their strategies.

The Great Game is a British term for what was seen by the British to be strategic rivalry and conflict between the British and the Russian Empire for supremacy in Central Asia. The classic Great Game period is generally regarded as running approximately from the RussoPersian Treaty of 1813 to the Anglo-Russian Convention of 1907. Following the Bolshevik Revolution of 1917, a second, less intensive phase followed. The term "The Great Game" is usually attributed to Arthur Conolly, an intelligence officer of the British East India Company ${ }^{1}$.

The importance of Eurasia as a World-island was recognized by Sir Halford J. Mackinder in his book Democratic Ideals and Reality in 1919, the same book in which the Heartland concept was introduced. Even before that, Mackinder had identified the area in the north and central part of Eurasia, and named it The Geographical Pivot of History (referred to also as Pivot) in 1904. He considered this area to be the most important part of the World, in terms of geostrategy (Sloan, 1999).

Mackinder's Pivot concept was introduced while the Great Game was still going on. Mackinder indeed realized the importance of territorial control over vast, continental expanses in the centre of the Eurasian landmass. It was a sparsely populated and developed area, but extremely difficult to reach from the sea, because of its remoteness and inaccessibility, especially considering the level of technological development a century ago: Although Mackinder changed the heartland boundaries according to the strategic context of the times - he applied his formula in 1904, 1919, and 1943 - its core element always included Central Asia (the present-day countries of Afghanistan, Kazakhstan, Kyrgyzstan, Tajikistan, Turkmenistan, and Uzbekistan), western Siberia, and the northern portions of Iran and Pakistan. Beyond the reach of sea power, because its rivers flowed into inland seas or the largely inaccessible Arctic Ocean, the region was "the greatest natural fortress on earth" (Seiple, 2004).

The contemporary strategic and economic relations in Central Asia cannot be separated from the complexity of strategic and economic relations in Eurasia as part of the Worldisland. Because of the importance of the region for the energy supply of the world, and renewed rivalry of the world powers, Mackinder's ideas should be studied to understand the basic principles of geostrategy, in this case particularly applied to the central part of Eurasia.

If Eurasia is a part of the World-island, in accordance with Mackinder's ideas, strategic and economic relations that influence this part of the world should be referred to as geostrategic and geoeconomic, because their importance affects the global level. The importance and indivisibility of relations in Central Asia from those in the neighboring regions, the involvement of the world's only superpower and two great world powers and their rival relations provide the reason to treat these relations at the level of global rivalry, and the region represents a prize and a testing ground of a strategic game, since 
the influence of the world's greatest powers is projected upon it. The interest of these great powers in Central Asia is defined by geostrategy and geoeconomy. Strategic and economic relations in Central Asia are characterized by the rival geostrategy of the USA and strategies of Russia and China, and the reason for their interest is mainly geoeconomic, since the region, together with the Caspian Sea, contains vast oil and gas fields. To control the fields and the export of oil and gas from the region, strategic capabilities and presence in the region are needed as a means to control the oil and gas transport infrastructure. Rival and confronting interests of the USA, Russia and China are the causes of strategic rivalry.

The map of Mackinder's Pivot was first published in the paper The Geographical Pivot of History in $1904^{2}$. Central Asia occupies the southern part of Mackinder's Pivot area, and therefore, according to Mackinder, has extraordinary strategic value. Central Asia is also a part of the Heartland concept, which represents a revised concept, but speaking in the terms of area, is a slightly expanded Pivot.

The geographical location of the region shows us that it represents a remote (from Western influence) and land-locked area. A vast transitional space, abundant in energy reserves, became an area of opportunity in the 1990s. It could become an even more significant area of opportunities, if instability, conflicts and great power rivalry were to be contained or at least kept at a minimal level. A comprehensive and feasible strategy, for the players involved in the strategic "game", should be used as a precondition for a successful and efficient geoeconomic agenda.

The reasons for using a feasible strategy for the region are the following:

1. The energy supplies are located in a part of the world which is very unstable and difficult to reach from neighboring regions, because of physical barriers and lack of infrastructure in the areas located south and southwest of Central Asia;

2. There are many rival, potentially hostile players in the international geopolitical arena that have a major goal in preventing the other players from becoming deeply involved in Central Asian affairs and gaining a larger portion of control over its energy resources;

3. A superpower from outside the region (USA) and a great power on the region's borders (China) inevitably want to skirt Russian territory in order to end forever the dependence on transporting and exporting Central Asian oil and gas through the Russian, ex-Soviet infrastructure. Their objectives are in opposition to those of Russia in retaining the dependence of oil and gas exports from Central Asia on its infrastructure;

4. Russian and Chinese objectives in Central Asia have come to the point where their rivalry is put aside to a large degree, in order to contain the rising influence of a more powerful contender to their own influence, the USA.

At present, it is possible to identify three primary strategies in Central Asia:

- US strategy for Central Asia, an important part of US global geostrategy, global by its reach and capabilities, which wants to penetrate the region and establish its influence. It is connected with the US strategy for the Broader Middle East region that includes Afghanistan and Iraq. Its postulates are dominated by US interests, with support from some European Allies (NATO members); 
- Russian strategy, super regional by its reach and capabilities, which wants to keep Western influence, especially the influence of the USA, out of Central Asia. Its second main goal is to keep Chinese influence in Central Asia as weak as possible, and, at the same time, to use it against the rising Western, predominantly US influence;

- Chinese strategy, super regional by its reach and capabilities, which also wants to influence the region, not so much with strategic capabilities, but with its economic and political influence that is rapidly rising.

Confrontation between the US and Russian strategies over a significant period and with significant efforts from both sides would mean that a new Great Game has evolved. In this new Great Game, the USA would be the side that wants to establish influence in Central Asia from southern parts of Asia. Since Russian influence was weak in the 1990s, and a sort of security vacuum existed, the USA managed to gain influence, but the real influence was established after the attack on Afghanistan and establishment of military bases in Central Asia. However, the Russian influence has returned in the meantime, and a new player, China, has entered the game. Iran and Turkey have also entered the game, but their influence and power cannot be compared with the power and influence of the USA, Russia and China.

\section{THE GEOGRAPHICAL DEFINITION OF CENTRAL ASIA}

Central Asia is a large geographical region that lies in the heart of Eurasia, and represents a continental, landlocked area. Definitions of this region vary, due to the lack of clear physical geographical borders in the northern part of the region. According to historical criteria and definitions, Central Asia occupies a vast space in the Eurasian heartland - from southern Siberia to northern Pakistan and Iran, and from the Caspian Sea to Inner China, containing all of the former Soviet Central Asia, but also Afghanistan, northern Pakistan (Kashmir), and the Chinese provinces of Xizang (Tibet), Xinjiang (Sinkiang) and Nei Mongol (Inner Mongolia), and the Mongolian Republic as well. That vast space would represent the broadest definition of Central Asia, according to historical definitions of the region called Turkestan. If we use climatic criteria, we can recognize that Central Asia is an area of predominantly dry (arid and semiarid) climates. Climate type BWk (cold desert climate) predominates in most of Central Asia, occupying central parts of the region, and to the north of this climate type, BSk climate type (cold semi-arid, steppe climate) predominates, followed by hot (Dfa) and warm (Dfb) summer continental climates. In the areas of higher elevation (mountains and highlands), the mountain climate type predominates. So, in general, we can say that Central Asia represents an area of dry and continental climates, which implies low precipitation and therefore the precious nature of fresh water. Mainly because of the dry climate, vast areas of the region are almost completely uninhabited.

The biggest part of Central Asia's area belongs to the endorheic basin (internal drainage system), which means that its rivers do not flow into the sea or into the ocean. The cause of this is Central Asia's location, in the interior of a huge continental mass, far from an ocean. Its rivers flow mainly into the salt lakes (the Caspian Sea, Aral Sea, Lake Balkhash etc.). The terrain of Central Asia is mostly comprised of deserts and treeless steppes. Mountains and highlands are located in the southern, southeastern and eastern (or central, if we consider Xinjiang, Tibet and Mongolia as parts of Central Asia) parts of the region. 


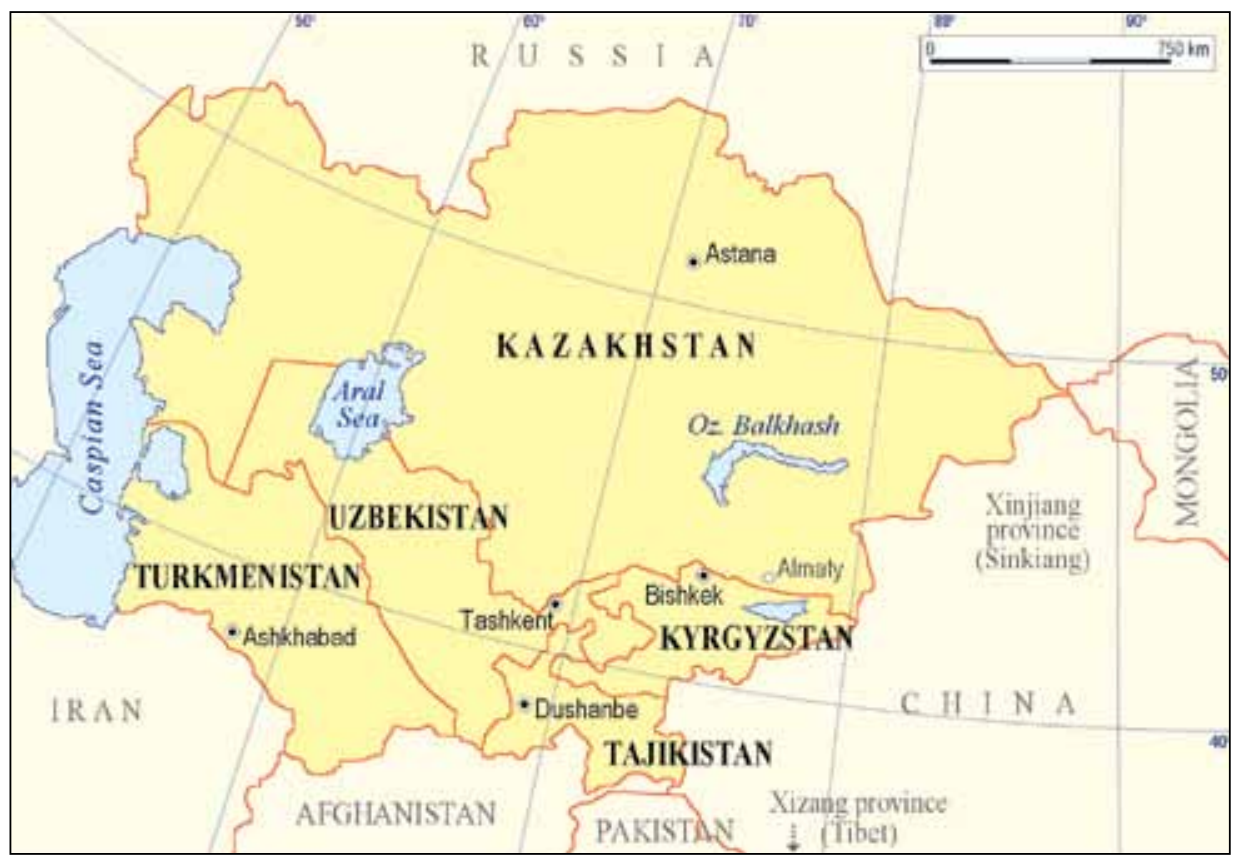

Fig. 1 Map of Central Asia

Sl. 1. Karta Središnje Azije

By ethnical and cultural criteria, the borders of Central Asia to the north are also not completely defined, since a mixture of Slavic (Russian) population with Kazakhs exists in Kazakhstan. The northern part of Kazakhstan therefore represents a Russian transition zone towards Siberia. Russian minorities are also present in other Central Asian countries, because of the Russian dominance and colonization of these areas that ended only in recent history (De Blij, Muller, 2004).

However, for the purpose of this paper, the political borders of the former Soviet Central Asia are used. They are defined as the outer borders of five countries, the former Soviet republics: Kazakhstan, Kyrgyzstan, Tajikistan, Turkmenistan and Uzbekistan. The areas that surround these countries belong to the countries that are parts of other political regions, and their core areas, as well as their principal population centers, are not in Central Asia (Russia, China). Mongolia does not belong to the geopolitical region of Central Asia, and did not share recent history with the other Central Asian countries, and Afghanistan, as a zone of transition and a buffer state, is divided between the geopolitical regions that surround it - the Broader Middle East region, Central Asia and South Asia. Azerbaijan, also studied in the paper because of its oil reserves and very important geopolitical position, is a Caspian Sea region country. The five countries that are referred to here as Central Asian occupy a territory of approximately four million square kilometers with about 60 million inhabitants. 
Tab. 1 Territory, population and GDP (PPP*) of Central Asian countries

Tab. 1. Površina, stanovništvo i bruto društveni proizvod* država Središnje Azije

\begin{tabular}{|l|r|c|c|c|c|}
\hline \multicolumn{1}{|c|}{ Country } & $\begin{array}{c}\text { Area in sq. } \\
\mathbf{~ k m}\end{array}$ & $\begin{array}{c}\text { Population } \\
\text { in 000, July } \\
\text { 2009 est. }\end{array}$ & $\begin{array}{c}\text { Population } \\
\text { density per } \\
\text { sq. km }\end{array}$ & $\begin{array}{c}\text { GDP } \\
\text { Billions of } \\
\text { International \$, } \\
\text { 2009 est. (PPP }\end{array}$ & $\begin{array}{c}\text { GDP per capita } \\
\text { of Internatio- } \\
\text { nal \$ 2009 est. } \\
\text { (PPP*) }\end{array}$ \\
\hline Kazakhstan & 2724900 & 15150 & 5.6 & 177.35 & 11369 \\
\hline Kyrgyzstan & 199951 & 5370 & 26.9 & 11.55 & 2227 \\
\hline Tajikistan & 143100 & 6500 & 45.4 & 13.03 & 2083 \\
\hline Turkmenistan & 488100 & 4885 & 10.0 & 33.39 & 5983 \\
\hline Uzbekistan & 447400 & 28250 & 63.1 & 72.55 & 2806 \\
\hline Central Asia & $\mathbf{4 0 0 3} \mathbf{4 5 1}$ & $\mathbf{6 0 1 5 5}$ & $\mathbf{1 5 . 0}$ & $\mathbf{3 0 7 . 8 7}$ & $\mathbf{5 1 1 8}$ \\
\hline
\end{tabular}

${ }^{*}$ Gross domestic product (GDP) shown in total and per capita Purchasing Power Parity (PPP) units. Bruto-društveni proizvod ukupno i po stanovniku iskazan prema jedinicama kupovne moći stanovništva.

Izvor: http://www.gfmag.com/gdp-data-country-reports.html

The Caspian Sea, which forms the western border of Central Asia, with its eastern part, also belongs to the region of Central Asia, and Turkmenistan and Kazakhstan possess a part of the Caspian Sea, which implies their strategic and economic importance, because of the Caspian Sea shore and off-shore oil and gas fields that make Central Asia a prime object of any relevant geostrategic study and any global military and economic strategy. The adamant connection between feasible geostrategies and geoeconomies is necessary for maintaining stable energy supply and the functioning of the economies of the USA, Europe and the rising East Asian economies, as well as India's economy. When it comes to energy supply, there is no successful energy strategy that does not include strategic action and strategic capabilities. Since the success of any strategy depends on the exclusion of as many detrimental factors as possible, the capability for strategic action is of the utmost importance.

\section{CENTRAL ASIA 1991-2001: A SLOW OPENING TOWARDS EXTERNAL INFLUENCE}

The Soviet Union broke up in 1991, leaving five former Soviet Central Asian republics as independent countries. Unfortunately, with independence, a period of their economic, political and social instability and downgrading began. The whole region became an area of fragile stability or even instability, with a security vacuum that followed after the breakup of the Soviet Union. Five independent countries found themselves in a deep economic crisis and crises of their societies, ruled by authoritarian presidents who held on to their positions from the Soviet era. A civil war in Tajikistan broke out, between the government and Islamist guerrillas, and the government, with considerable Russian aid in arms and men, won it. The countries that were once Soviet republics now had their own internal borders, which were carved up in Moscow during the Stalin era, and had deliberately left large ethnic groups, especially the Uzbeks, outside the administrative borders of their 
republic. This fact presents a large problem for the stability of Central Asia, since the ethnic minorities want the areas where they live to belong to the country considered the homeland of their nation. Another problem of the newly independent countries of Central Asia also consisted in facing their internal Russian minorities, the largest minority being in Kazakhstan, where Russians at the time of the Soviet Union's breakup comprised almost 40 percent of the population. Russia claimed care of its minorities in the so-called "near neighborhood states" (former Soviet republics) as one of the top objectives of its National Security Strategy, in 1993. However, since then, the number of Russians living in Central Asian countries has significantly decreased, but not as a result of violence against them.

The natural resources of Central Asia are significant: blessed with oil, natural gas, cotton, gold, and hydroelectric potential, the Central Asian economies are also growing strongly and stepping away from their post-Soviet decline. Economic growth has been strong in the post-Soviet era, fueled by gas and oil deposits in Kazakhstan, and Turkmenistan; gold in the Kyrgyz Republic; and, cotton in Uzbekistan. However, the Central Asian countries remain relatively poor, and a gap is opening up between those countries with oil and gas, and those without. Per capita incomes (GDPs) in the oil producers in 2007 were already more than double those in the Kyrgyz Republic, Tajikistan, and Uzbekistan (Savas, B., 2008).

All Central Asian countries suffered a steep decline in GDP per capita in the first half of the 1990s. The main reasons lie in the breakup of the Soviet Union, the loss of traditional markets and complete unpreparedness for a market economy. The economic transition was a heavy blow to the Central Asian economies. In the second part of the 1990s, GDP per capita started to rise (with the exception of Tajikistan, which had a GDP per capita at about half of the value from 1990). The rise of GDP per capita was a characteristic in 2009 as well, but only Kazakhstan and Turkmenistan managed to raise their GDP per capita above the 1990 value. Thanks to oil exports, Kazakhstan alone produced about 58 percent of the region's GDP in 2009, with only about a quarter of the region's population.

In general, we could say that five dominant groups of regional security challenges in Central Asia and the Caspian Sea region emerged after the breakup of Soviet Union:

1. The slow-burning fuse and consequences of an enfeebled application of Russian power and influence;

2. The legal confusion over the definition of the Caspian Sea's status and the inability to obtain agreement by all the five riparian states $^{3}$;

3. The emergence of historic, regional, and power rivalry which is taking shape between Russia and China, Russia and the USA, either in relation to their hydrocarbon and mineral deposits or due to the suitability of their territory for the transport of oil;

4. The extension of Western influence through the presence of North American power, investment and global corporate experience, together with the return of traditional European commercial interest, acumen and technical expertise;

5. Serious questions arose with regard to environmental and ecological issues, especially the decline in the Caspian fishing industry, to some extent caused by the negative effects of oil exploration in conservation areas and the real concerns generated by the rising sea level of the Caspian Sea (Blandy, 1998). 
The possibility that Central Asia could be left outside some sphere of influence in the future does not seem realistic. It is exposed to the risk of instability, since it is encircled by rival regional powers as well as great powers, which are also physically present in Central Asia, through their military bases.. To the contrary, Central Asia does not have a power centre that would be strong enough to become a guarantee of stability. Centrifugal forces in the region are strong, due to territorial disputes, ethnic differences and the heterogeneous ethnic composition of the countries of Central Asia. Fragmentation of Central Asia into five countries, each having some kind of disputes with its neighbors, causes the fact that none of the Central Asian countries meets the preconditions to become a real regional power with the capability to organize the area hierarchically. All these factors make Central Asia a very suitable area for fragmentation, instability and maybe even its turning into a shatterbelt, which would be linked to the shatterbelt that exists in the Middle East (Fuller, 1994).

The description of security relations in Central Asia in the first half of the 1990s shows that the region was left in a sort of a security vacuum after the Soviet Union broke up. Russian influence was too weak to stabilize the region. The outside influences were too weak to destabilize it, since they would certainly have met with Russian reaction, no matter how weak Russia was then. Russian power and closeness to the region have always been significant enough regarding the relations of Russia and any Central Asian country in particular. Central Asian countries are all weak powers, compared to Russia. Chinese and other influences outside the region were also weak in the 1990s, and they could not jeopardize the position of Russia, whose influence in the region gradually started to rise again, at the end of the 1990s.

In the West, the best way to make Central Asia an area of opportunity and stability was to develop and apply a new strategy of involvement and projection of security to Central Asia, which would take a high position on the level of Western foreign and security policy goals. The region was perceived as an area of vast oil and gas reserves (Brzezinski, 1997a).

At the same time, the region became open to influences from outside, and because of its strategic importance, these influences started to move in. The political elites of five Central Asian countries are open to outside influences, balancing between them all the time. Their political weakness and legitimacy is completely disproportionate to their openness to outside influence, authoritarianism and undemocratic government. Although some predicted a struggle for influence would evolve in Central Asia between the rival outside powers, that did not happen during the 1990s, so the predicted new Great Game failed to be realized (Buzan, Waever, 2003).

When did the new Great Game begin to evolve? Actually, there was no real new Great Game until the USA started to penetrate Central Asia. The new Great Game started to evolve in a different manner after September $11^{\text {th }}$, and the establishment of military bases of the USA in the region, as well as with the occupation of Afghanistan ${ }^{4}$, which again became an important geostrategic gain, as a country that ties three strategically important geographical regions - Central Asia, the Middle East and South Asia.

After the breakup of the Soviet Union, US policy towards Central Asia was mainly oriented toward promoting regional cooperation, and political and economic stability. In its implementation, the USA inclined to multilateral institutions and programs. NATO's 
Partnership for Peace program included Central Asian countries, so that stability, security and cooperation could be projected into the region (Aydin, 1999). Now it is also focused on the fight against terrorism, drugs and human trafficking and illegal arms sales.

Western economic interests were complemented by NATO's growing awareness and involvement, in addition to the treaty ties and activities associated with Turkey as a member of the Alliance, and, resulting from this, the strategic importance of the Caspian Basin as an energy reservoir, appearing in some respects as an alternative to the Persian Gulf; the Conventional Forces Europe (CFE) Flank Zone Agreement; and, finally, increased activity in the NATO Partnership for Peace (PfP) program in both the Caucasus and Central Asia as part of NATO's expansion policy (Bronson, 1998).

The Central Asian Economic Community (after 2002, it became Central Asian Cooperation) was formed, but it was not a significant factor. The Commonwealth of Independent States (CIS) de facto split into two groups of states, with one group gathered around Russia (Armenia, Belarus, Kazakhstan, Kyrgyzstan and Tajikistan) and the other (Azerbaijan, Georgia, Moldova, Turkmenistan, Ukraine and Uzbekistan) gathered against Russian predominance in the CIS. Several CIS states rejected the May 1992 Treaty on Collective Security, or Tashkent Treaty, which Moscow had initiated as a "regional security structure" within the CIS. In May 2002, the Collective Security Treaty of the CIS renamed itself the Collective Security Treaty Organization (CSTO), with the stated focus of preserving territorial integrity and seeking closer cooperation with other multilateral institutions, such as the United Nations, Organization for Security and Cooperation in Europe, Shanghai Cooperation Organization (SCO), and NATO. The CSTO serves as a mutual defense alliance. Russia's clear pre-eminence within the organization limits its legitimacy ${ }^{5}$.

An organization called GUUAM Group (members: Georgia, Ukraine, Uzbekistan, Azerbaijan, Moldova) is oriented towards closer cooperation, political and economic, and against Russian predominance in the CIS. GUUAM was formally founded as a political, economic and strategic alliance designed to strengthen the independence and sovereignty of former Soviet Union republics. GUUAM became an important structure, looking to enhance regional economic cooperation through development of a Eurasian, Trans-Caucasus transportation corridor (TRACECA).

One important regional organization, called the Shanghai Cooperation Organization (SCO) was formed in 1996. It is an intergovernmental security organization, that includes China, Russia, Kazakhstan, Kyrgyzstan, Tajikistan, and, since 2001, Uzbekistan. The SCO is an organization that actually directly confronts US influence in Central Asia, since Russia and China, through membership in it, are connected with Central Asian countries. The character of the SCO is shown by the fact that the USA applied for membership, but its application has been rejected. One of China's main reasons for increased participation, besides geoeconomic and geostrategic interests, is security interests and concerns over separatism in the Xinjiang Uyghur autonomous province, among the Uyghur population. China accuses the Uyghur separatists of being connected with Islamists in Central Asia. One of the goals of the SCO is security cooperation and the struggle against terrorism, which is unfortunately often used as an excuse by regimes in Central Asia for crackdowns 
on the opposition. The sparsely populated Xinjiang province (with an area of more than 1.6 million square $\mathrm{km}$ ) takes up about one sixth of China' territory, and represents China's western frontier. The region has about 20 million inhabitants, about 45 percent of whom are Uyghurs, and about 41 percent Han (Chinese). China is trying to connect the region with the Chinese core, develop it, and settle Han population there (similar policy has been implemented in Tibet). Cooperation and economic ties, and trade and investments in Central Asian countries represent a way to develop the Chinese western frontier, which represents the entrance to Central Asia and a frontier towards Russia.

\section{THE CASPIAN SEA OIL AND GAS RESERVES: A PRIMARY GEOPOLITICAL GOAL}

The Caspian Sea basin, which is a primary geopolitical goal for all geostrategies and strategies and any geoeconomy focused on energy resources, represents, by the postulates of geoeconomy, a giant reservoir of oil and gas that could play an important role in the energy and, of course, economic future.

Caspian Sea oil and gas will play a major role in the energy strategies of the great powers. They want to control these energy resources that have a possibility for increased exploitation and exports onto world markets, greater than the Middle East reserves that have been exploited significantly more so far. But the export of this oil and gas to world markets demands a struggle with huge geographical barriers, as well as geostrategic and geopolitical challenges and the odds are not so prospective (O’Lear, 2004).

The oil of this region is considered to be of good quality. The biggest part of this oil is intended for export, since the needs of the producing countries are relatively low and are expected to remain low. The fact that the countries of the region lack the capital and the technology to proceed independently to the development of these oilfields offers American companies considerable investment opportunities.

The struggle for Caspian energy resources that started right after the independence of the Central Asian countries and Azerbaijan was actually a quest for laying down pipelines and buying concessions over Central Asian oil and gas fields. The first agreement on oil exploitation was signed in 1993, between the American company Chevron and the Kazakhstan government, for a period of 40 years. It included exploitation of the Tengiz oil field, the largest in Kazakhstan, with the oil to be transported to the Russian port of Novorossiysk on the Black Sea. The USA has since then remained continuously interested in gaining influence in the three key countries that possess (with Russia and Iran) shores on the Caspian Sea as well as parts of its waters and bottom: Turkmenistan, Kazakhstan and Azerbaijan. With their neighboring countries: Armenia, Georgia, Turkey, Ukraine and Uzbekistan they represent very important area for the USA, because of their economic, political and strategic importance. Therefore, Central Asia is of prime geostrategic importance. It is one of the central factors of European security, its remoteness from the European core notwithstanding. The dependence of the Central Asian countries on Russia in trade, economy and transport is still very strong. The USA, however, is giving the greatest support to the building of oil and gas pipelines, so that diverse transport possibilities for 
Caspian Sea oil and gas to regional and world markets will be available. Caspian Sea oil would help in the stabilization of the world oil market, so that the price of oil would not go "sky high" in the future. Caspian Sea oil reserves that have been verified so far include at least 115 billion barrels of oil. If capital from the oil industry were to be transferred to other sectors of the economy like infrastructure, telecommunications and transport, other companies besides American should also make profits (Kalicki, 2001).

Kazakhstan has massive untapped oil fields in Kashagan (the largest oil discovery in the past 27 years) and Tengiz (an oil field that is comparable in size to the former, discovered in 1979), with its low domestic consumption and growing export capacity. Its prospects for increasing oil production in the 2010-20 time frame are impressive, given the recognized potential offshore in the North Caspian (Nanay, 2005).

However, it is very doubtful how much benefit that would bring to the citizens of Central Asian countries, since their governments and societies are among the most corrupt in the world ${ }^{6}$. The vastness of oil and gas reserves in Kazakhstan and Turkmenistan, and basically a lack of such reserves in the other three countries of the region, implies that the two oil and gas rich countries are a geoeconomic grand prize in the geostrategic and geoeconomic contest for control over energy resources in Central Asia and the Caspian Sea region: a new Great Game. The closeness of oil and gas fields to the Caspian Sea or their location under its surface exemplifies the need to treat Central Asia and the eastern part of the Caspian Sea as a single economic area, exposed to the similar geostrategic contest in pursuit of the similar geoeconomic goals of the rival players.

Having 30 billion barrels of proved oil reserves, Kazakhstan ranked $12^{\text {th }}$ in the World, and Azerbaijan ranked $20^{\text {th }}$, having seven billion barrels. Turkmenistan ranked $42^{\text {nd }}$, having 600 million barrels, and Uzbekistan ranked $43^{\text {rd }}$, having 594 million barrels. Saudi Arabia ranked $1^{\text {st }}$ in the World, having 266.8 billions of barrels and Croatia ranked $66^{\text {th }}$, having 79.15 million barrels. The total proved oil reserves of the World in 2009 were 1332 billion barrels.

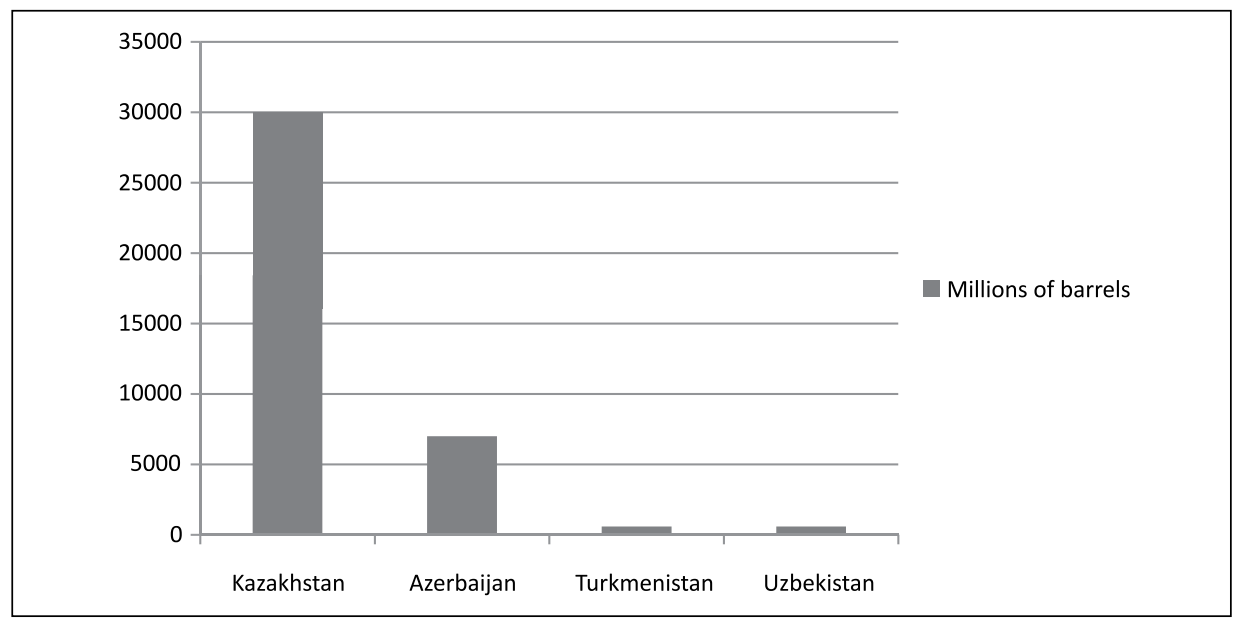

Fig. 2 Proved oil reserves of Central Asia and Caspian Sea region countries with significant oil reserves, 2009

Sl. 2. Potvrđene zalihe nafte u državama Središnje Azije i regije Kaspijskogjezera koje imaju značajnije zalihe nafte, 2009., u milijunima barela 


\section{RIVAL STRATEGIES IN CENTRAL ASIA: IS THE NEW GREAT GAME A REALITY?}

All attempts made to influence the internal conditions in Central Asian countries from outside the region have not achieved significant success so far. A functioning democracy, rule of law, market economy, democratic oversight of armed forces and transparent civilmilitary relations still represent a "mission impossible" for the Central Asian countries. The means to achieve these goals that have been successful in Central and parts of Eastern and Southeastern Europe prior to their accession to the EU and NATO are simply not suitable for Central Asia. So the West has never seriously considered Central Asian countries as possible candidates for membership in the security and political organizations of the EuroAtlantic community, because they cannot and do not want to fulfill the criteria. Attempts from the West to resolve some instabilities and rivalries among the Central Asian countries without the inclusion of Russia seem virtually impossible. Since Russia is not insisting on these criteria in bilateral relations, Russian influence is returning to Central Asia and it is becoming stronger every day.

The main goal in the geopolitics of Central Asia and the Caucasus is control of the transportation of oil and gas. For some, this is about energy per se (China), for others, mostly about the economic implications (the countries in the region and to some extent Turkey and Iran, and the oil companies); to others again it is mainly a way to gain influence and/or prevent others from doing so (the USA and Russia, in particular). The struggle is basically about the politics and economics of competing pipeline projects to connect the Caspian Basin hydrocarbon resources to world markets, via Russia and the Black Sea, via the Caucasus and Turkey, via Iran, via Afghanistan, or via Kazakhstan to China (Buzan, Waever, 2003).

The Western strategy for Central Asia is therefore oriented towards fulfillment of these primary strategic objectives of the West:

1. Keep the flow of oil and gas from Central Asia and the Caspian Sea to the USA and Europe permanent and unobstructed;

2. Build an infrastructure of pipelines that would completely skirt Russia (and Iran), and open up the Central Asian energy reserves to the world markets, reducing the possibility of obstruction and blockade of pipelines that Russia could impose;

3. Keep Russian and Chinese influence as weak and distant as possible. This is a very difficult task now, and in the future it will not be much easier;

4. Reduce security challenges to the most minimal possible level. By this, we consider the fight against terrorism, drug trafficking, and proliferation of weapons of mass destruction.

Washington's attempt to diminish Russian influence has been part of a policy aimed at wresting Central Asia and the Caucasus from its sphere of influence by any means, including oil and gas pipeline construction, pressure by NATO allies, financial incentives for docile local leaders, and alignment of US media with others who oppose Russian alliances. The new approach, coordinated by the US National Security Council, was designed to break Russia's grip on Central Asian oil export. The objective was both to help ensure 
the survival of independent countries in the region and to protect U.S. corporate interests (Yazdani, 2006).

Russia wants to keep Central Asia in its own sphere of influence. Russia should consequently do more to resist Washington's penetration. Russian geostrategy is also developed for the fulfillment of geostrategic and geoeconomic objectives in Central Asia. It is directly opposed to the Western geostrategy, while ambivalent to the Chinese strategy at present. Its specific goals are determined by Russian historical ties and influence, as well as Russia's dominant geographical position and export infrastructure that still largely passes through the territory of Russia. So the Russian geographical location gives Russia numerous strategic and economic advantages. Russia's primary goal is keeping the Western influence out of Central Asia as much as possible, as well as to contain Chinese influence if it is not useful in keeping Western influence out of Central Asia. Strengthening its own influence in relation to the Western influence, since this is a zero-sum game, is obviously the best strategic postulate to achieve the strategic objectives. Using China when necessary is a way to take a united stand against the influence from the USA.

On the lower levels, concerning the capabilities of these countries for action, Iranian and Turkish strategies for Central Asia and the Caspian Sea region also exist. They are combined with the strategy for the Caucasus, as the adjacent and strategically very important area for Central Asia and the Caspian Sea region. The Caucasus represents a transit area for the oil and gas from Central Asia and the Caspian Sea region, through which pipelines that circumvent Russia and Iran transport of oil and gas to the Western markets. Both countries want to be interregional powers, and they want to broaden their influence into the neighboring areas. Their areas of interest and influence significantly overlap, while their orientation is quite opposed. Turkey is an ally of the West, and Iran is the primary adversary of the USA in this part of the world.

The Iranian strategy is mostly concerned with the strengthening of its own influence in the neighboring countries: Turkmenistan (with abundant gas reserves) and Azerbaijan (also with abundant oil reserves) that has mostly Shiite population (the Azeri are Shiite, as are the Iranians, and more Azeri live in Iran than in independent Azerbaijan). So Iran is using these ties to gain influence in Azerbaijan, but is confronted with the American influence, which is adversarial to any notion of Iranian influence and to the possibility that the Caspian Sea oil would flow through the Iranian pipelines. Azerbaijan is a country that lies at the entrance to the Caucasus region, and Turkmenistan is a country that, from the Iranian perspective, lies at the entrance to Central Asia. Iran wants the Caspian oil (from Azerbaijan and Kazakhstan) to flow through its pipelines to the ports of Abadan, Bandar Abbas and Bandar Khomeini, from where it would be exported to world markets by sea. Establishing influence in Azerbaijan and Turkmenistan, as well as Kazakhstan, would be key to the success of Iranian strategy in the region. However, the Iranian influence has been contained so far by the US presence in Azerbaijan, as well as Turkish influence in the Caucasus and the Central Asian states.

Turkey, a country that is allied to the West, a NATO member-state and an ally of the USA, has interest in becoming an inter-regional power, by engaging in Caucasus, Caspian Sea and Central Asian affairs, and strengthening its role as a key ally of the USA in the part 
of the world that is strategically one of the most important. As a country that connects the Middle East region, The Gulf, South-Eastern Europe, the Caucasus and the Caspian Sea region, Turkey serves as a land-bridge, and even a gateway between these regions. Turkey is also a country that imports energy, oil and gas, and wants to establish its influence in the oil and gas-producing countries of the region, as well as to diversify its supply. Turkey is a transit country for new pipelines that have been built from the Caspian Sea across the Caucasus to the Mediterranean Sea, over Turkey, and bypassing Russia and Iran, in accordance with the interests of the West. Contrary to most of the regions and countries that surround it, Turkey is a strong and what is most important - a stable country - a loyal and valuable ally of the West, with its own interests in the surrounding areas, which do not collide with Western interests. The fact that Turkic peoples comprise the majority of the population in Central Asian countries (except in Tajikistan), as well as in Azerbaijan, shows great possibilities for Turkish cultural influence, that can be followed by economic and political influence. Turkey has established connections with the countries of Central Asia, and the Turkish, secular kind of Islam is much more acceptable to the regimes and the people in Central Asian countries than the Iranian kind of Islam, particularly concerning the role of the Islamic clergy in political structures. This is completely understandable, since Central Asian peoples are Sunni, and not Shiite, and the strong secular influence of the Russian and Soviet eras in Central Asian societies is still strong, and will not be easily overridden.

\section{THE CENTRAL POSITION OF UZBEKISTAN IN CENTRAL ASIA}

Contrary to the US policy in the 1990s, a more realistic approach prevailed after September $11^{\text {th }}$. This approach promoted Uzbekistan as a regional hegemonic country, since it was the central country that bordered all countries of the region, and was the most populous country having about 45 percent of the region's population. There are Uzbek minorities in the neighboring countries of Uzbekistan as well. After the USA decided to invade Afghanistan, it needed help from Uzbekistan. The USA needed military bases and transit corridors to wage war in Afghanistan. After having driven the Taliban from power, the USA gave undeserved importance to Uzbekistan and its authoritarian president Karimov, and the relationship included direct exchange of strategic resources. The reason for such US policy lay in Uzbekistan's geostrategic importance. The USA, Russia and China were all struggling for influence over Uzbekistan. And Japan also has an economic interest in Uzbekistan (Jones Luong, Weinthal 2002).

The USA and Russia have primarily opposing strategic interests in Uzbekistan, backed by opposing economic interests. China and Japan also have opposing economic interests. The USA wants the oil and other resources from Uzbekistan to flow more to Japan than to China. If the USA decided to raise Uzbekistan to the level of regional hegemon, that would be a mistake and it would basically affect Central Asian insecurity.

The authoritarian president of Uzbekistan, Karimov, who was a key ally of the USA in the region after its strategic entry into the region, felt threatened after the massive riots in 2005, which were most intensive in the north eastern part of Uzbekistan, where Ferghana Valley lies. This is the core area of Uzbekistan. Riots and protests against the 
government were massive, especially in the city of Andijan. After condemnation from the West, Karimov decided to turn his back to the West, and oriented himself towards Russia. He ordered the Americans to withdraw from the airbase they had in Uzbekistan, called Karshi-Khanabad. So the Americans withdrew from Uzbekistan, but they established a base in Kazakhstan, still having another base in Kyrgyzstan, which had been established after September $11^{\text {th }}$, with the purpose of ensuring efficient war-waging against the regime in Afghanistan. However, their presence continued long after the ousting of Taliban regime from power. The geopolitical balance in the region shifted towards Russia. Karimov also signed a treaty of mutual military assistance and defense with Russia. The treaty goes so far as to establish the institution of collective defense. Article 2 of the treaty states: "If an act of aggression is committed against one of the sides by any state or group of states, this will be viewed as an act of aggression against both side the other side... will provide necessary assistance, including military assistance, as well as giving aid through other means at its disposal" (Treaty of Alliance Relations between Russia and Uzbekistan, November $\left.14^{\text {th }}, 2005\right)$.

The Treaty was an important step for the return of strong Russian influence in the region and it gave Russia an opportunity to improve its relations with other Central Asian countries that turned themselves towards the USA after September $11^{\text {th }}$, and after the USA became physically present in Central Asia. Russia already has security treaties with Kazakhstan, Tajikistan and Kyrgyzstan, but the treaty with Uzbekistan binds Russia to defend Uzbekistan if it were to be attacked.

However, if the USA were to manage to achieve dominant influence in Uzbekistan, the balance of power in the region would be seriously disturbed. Uzbekistan would become a US outpost, an ally and a regional hegemon. The original interest of the USA in Uzbekistan turned into an important part of the new Great Game, with the USA, Russia and China as main players. A strategy for realization of much more important strategic and economic interests lay behind the proclaimed cooperation and struggle against terrorism and other contemporary security challenges. This is the true nature of the US geostrategy and geoeconomy for Central Asia. The shift that happened was a classic example of one country that is important geopolitically and even geostrategically, changing its foreign policy orientation and moving from one to the other rival side. By establishing strong connections with Uzbekistan, Russia prevented China from entering into the region with its military capabilities and from establishing physical presence with a military base on the territory of a Central Asian country for the first time. Japan will continue its economic competition with China, although its prospects in comparison with China are poor.

It seems that the USA and European Union have given up on Uzbekistan as an ally, although Uzbekistan has remained a member of NATO's Partnership for Peace, its membership is almost insignificant for the strategic interests of the USA and Europe. It still remains to be seen how the strategic game of control over energy resources will be conducted. But the strategic withdrawal of the USA from Uzbekistan was a definite blow to US geostrategic objectives, since the establishment of military bases in Central Asia was one of the means for their realization. Uzbekistan is one of the most problematic countries in terms of the great power struggle for dominance in the strategically important area, which includes Central Asia, the Middle East and Northern Africa. 


\section{THE US STRATEGY AND ITS SUCCESSES IN CENTRAL ASIA AND THE CASPIAN SEA REGION}

The USA started to improve its relations and strengthen its ties with Kazakhstan, Kyrgyzstan and Tajikistan, after its geopolitical defeat in Uzbekistan. These three countries are strategically important since they border China. The USA wants to contain Chinese and Russian influence in these countries as much as possible. The attainment of this objective depends on future US geostrategic objectives and on the level of cooperation between Russia and China in the containment of American influence in Central Asia. If the USA manages to assure its position in the Middle East, the Caucasus and the Caspian Sea regions, then these three countries, and especially Tajikistan and Kyrgyzstan, will not be so important. But it is very difficult to imagine that the world's only global superpower can limit itself to a selective geostrategy, when areas of such great strategic value are at stake; by withdrawing its influence, the USA would additionally expose the area to China's economical and political influence. In any projected and acceptable scenario, the USA would not want that to happen.

Through implementing its global strategy, the USA wants to establish control over the heart of Eurasia (Mackinder's Heartland: who controls it, is able to establish world domination) and it needs to be present over the large area from the East and Southeast of Europe, and over the Caucasus and Central Asia to Afghanistan.

Since the USA is already present in Iraq, and has military bases in some of the Gulf countries, it is already successfully preventing any other influence in those regions. The US Air Force is able to threaten every important pipeline and communication in Central Asia, because of its presence in bases in Iraq, Afghanistan and Central Asia. This is the most important strategic gain for the USA (Engdahl, 2004).

The traditional role of Afghanistan used to be that of a buffer state between the Russian and British empires. Until the Soviet intervention, in 1979, no outside force has exerted crucial influence in Afghanistan (McLachlan, 2000).

After the Soviet withdrawal in 1989, Afghanistan became a failed state, and the Taliban movement seized power. Since they were largely responsible for the September $11^{\text {th }}$ attacks, the USA decided to attack the Taliban regime in Afghanistan and to eject it from power.

This first US entry into Afghanistan and Central Asia shifted power relations into the region. Because of its geographical location, Afghanistan controls communication between South Asia and Central Asia. It also borders Iran, the main US adversary in the region, and since the USA is occupying Iraq, Iran is surrounded. The motives for attack on the Taliban regime in Afghanistan are clear, if we recognize the fact that the USA had supported that same regime in the 1990s, because of a planned oil and gas pipeline that should have originated in Turkmenistan, passing through Afghanistan and terminating in Pakistan on the Arabian Sea. But the Taliban regime almost completely blocked the construction of that pipeline, so the USA had no alternative but to remove the regime, since its strategy of control over energy resources and building pipelines for transport of oil and gas from Central Asia came completely into question. Even if September $11^{\text {th }}$ had never happened, the USA would still have gone to war with the Taliban regime in Afghanistan, 
probably according to the same plans and schedule. Plans for destruction of the Taliban regime were an object of diplomatic - and not so diplomatic - discussion months before September $11^{\text {th }}$ (Johnson, 2004).

After three main US military air force bases were built in Afghanistan further to the occupation of the country (in Bagram near Kabul, in Qandahar and at Shindand in the province of Herat, 100 kilometers from the Iranian border), it was planned to build nine more military bases after 2004, in the provinces of Helmand, Herat, Nimruz, Balkh, Khowst and Paktia. Afghanistan was a pivotal country in the British-Russian Great Game for control over Central Asia in the late nineteenth and early twentieth century. The British strategy was to keep the Russians out of Afghanistan at any cost. For US military planners, Afghanistan has a major strategic position, since it can be used as a platform that presents a direct threat to Russia and especially to China, and controls the southern access to Central Asia. Afghanistan is located in a vitally important position that connects South Asia, the Middle East and Central Asia. The Pentagon also managed to conclude an agreement with Kyrgyzstan to build the strategically important Manas military base, adjacent to the airport of the capital of Kyrgyzstan, Bishkek. From Manas, it is easy to observe or jeopardize the oil and gas fields and infrastructure in the Caspian Sea region, as well as the territory of Russia and China (Engdahl, 2007).

Before the attack on the Taliban regime in Afghanistan and American entry into Central Asia, American companies were unsuccessfully trying to get concessions for oil field exploration in Azerbaijan, Kazakhstan and Turkmenistan, and for the building of oil pipelines to export oil from these countries to the ports on the Black and the Mediterranean Sea, across Turkey. After the Americans started to build military bases in Kyrgyzstan and Uzbekistan, neighboring oil-producing countries, the climate for American oil business in the region improved significantly. American military power and presence in Central Asia is strategically and systematically used as an instrument of security and pressure on these countries, inducing them to grant concessions for oil exploitation and transport to American companies.

In the pursuit of geostrategic and geoeconomic goals, the policy of American continuous presence in Central Asia would have to be encouraged at all times, so that the leaders of Central Asian countries would not consider a short-term agenda that would soon disappear. An instrument that was intended to be an instrument of confidence-gaining was the Greater Central Asia Partnership for Cooperation and Development or GCAP, a regional forum for planning, coordination and application of American programs for Central Asia, in which the region would be recognized as unified, connected by common interests and needs. Trade is the key in the region's development, demanding major improvements in the transport infrastructure. Trade was rather well developed before the Soviet southern border completely separated Central Asia from its southern neighbors. The Great Game between the Russian and British Empires had not represented a barrier to the trade that had been well-developed on the local and regional level at the time. Some of these links and traditions, adapted to the contemporary era, should be re-established, especially between the five Central Asian countries and Afghanistan, Pakistan and India. The lack of transport infrastructure is one obstacle that has to be overcome (Frederick Starr, 2005). 
The cornerstone of Western energy security concerns in the Caucasus is the strategic $1,650 \mathrm{~km}$ Baku-Tbilisi-Ceyhan (BTC) pipeline, which plays a key role in ending Russia's monopoly over energy routes from the Caspian and offers the West an alternative means for transporting Caspian oil outside of Russian control. The South-Caucasus Pipeline, which lies parallel with the BTC, transports gas from the region, outside of Russian or Iranian territory and influence. The U.S. could have invited Russian companies to join in building a Trans-Caspian pipeline to connect the Kazakhstani fields of Tengiz, Karachaganak, and Kashagan to the BTC, but it had not done so, because of geopolitical reasons. However, to achieve fully the objective of the Baku-Ceyhan pipeline, the USA must use its influence on the governments of Kazakhstan and Turkmenistan for guaranteeing the construction of a pipeline under the Caspian, as one of the links of the Baku-Ceyhan system, and by doing that to increase the economic efficacy of the project. However, as the USA is expecting to boost the global oil supply through the BTC, Kazakhstani supplies to that route will be increasingly important. American companies also hold a major share in oil exports from Azerbaijan.

Producing 1445000 barrels of oil per day in 2009, Kazakhstan ranked $21^{\text {st }}$ in the World, and Azerbaijan ranked 23 ${ }^{\text {rd }}$, producing 1099000 barrels per day. With 180400 barrels per day, Turkmenistan ranked $44^{\text {th }}$. For comparison, Russia ranked $1^{\text {st }}$ in the World, producing 9980000 barrels per day, and Croatia ranked $77^{\text {th }}$, producing 17580 barrels per day. The total oil production of the World in 2009 was 85540000 barrels per day.

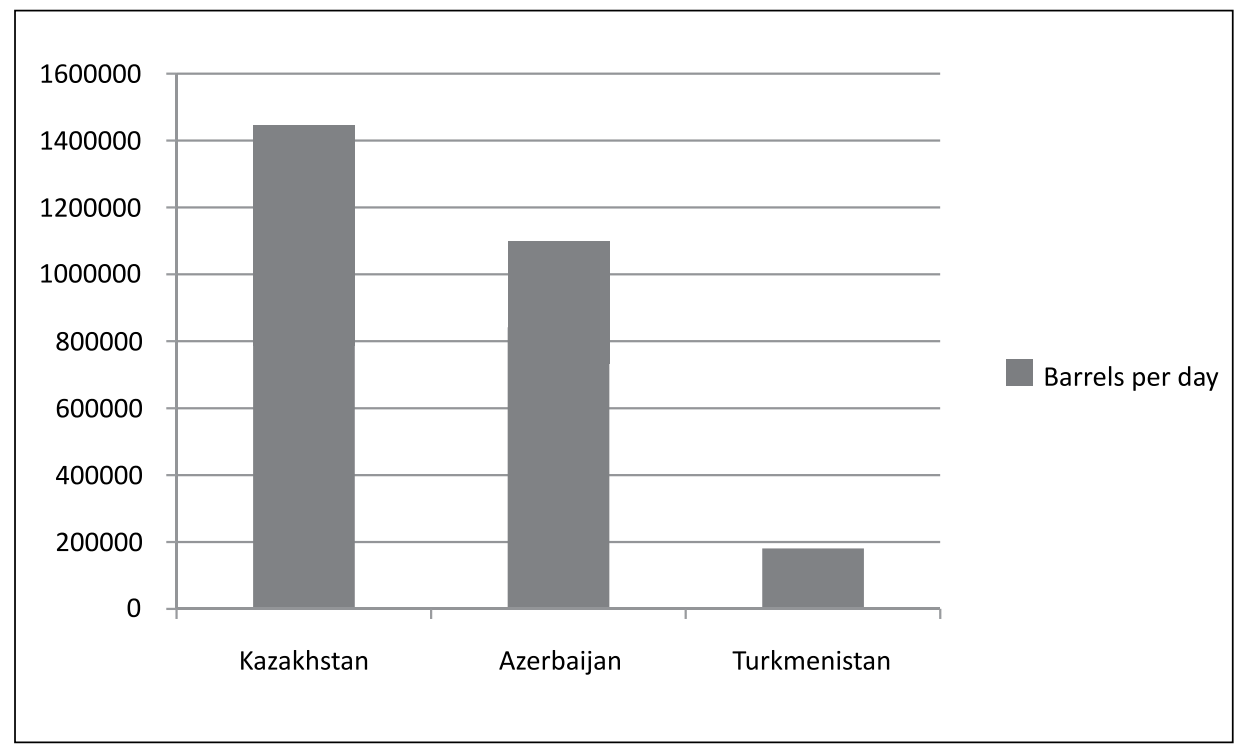

Fig. 3 Oil production of Central Asia and Caspian Sea region countries with significant production, 2009

Sl. 3. Proizvodnja nafte u državama Središnje Azije i regije Kaspijskogjezera koje imaju značajniju proizvodnju, 2009., u barelima dnevno 


\section{RUSSIAN GEOPOLITICAL AND GEOECONOMIC GAINS IN CENTRAL ASIA AND THE CASPIAN SEA REGION}

Russia did not wait long after the American geopolitical offensive in the eastern part of Central Asia, which was a response to the withdrawal from Uzbekistan. According to the policy of continuous strengthening of its position in Central Asia, former Russian president Putin signed an agreement with Kazakhstan and Turkmenistan to build a new gas pipeline that would follow the eastern shore of Caspian Sea, and the modernization of existing gas pipelines in the region, as well as complete modernization of oil and gas pipelines in Central Asia that would also include Uzbekistan. These pipelines are in direct competition to the Trans-Caspian pipeline that would be constructed on the bottom of Caspian Sea, between Turkmenistan and Azerbaijan, and financed by the West. Turkmenistan and Uzbekistan decided that they would export oil and gas through the route that would be cheaper and more efficient. The pipeline would follow the eastern shore of Caspian Sea and transport gas from Turkmenistan and Kazakhstan through Russia and then to Europe (Singh Roy, 2007).

It is also important to stress that Russia has a strong position only on the northern and eastern part of the Caspian Sea, with its own oil fields on the northern and north-western shores of the Caspian Sea, mainly around the Volga River delta, and its interests in Kazakhstan and Turkmenistan. Turkmenistan is a country that represents a very valuable geoeconomic and geostrategic gain for any great power outside the region that would be able to control its energy resources. Turkmenistan lies in the south western part of Central Asia. It borders Iran in the south, Afghanistan to the south and east, Uzbekistan to the east and north, and Kazakhstan in the north. The Caspian Sea basin represents its western border. The power that would manage to control Turkmenistan's energy reserves

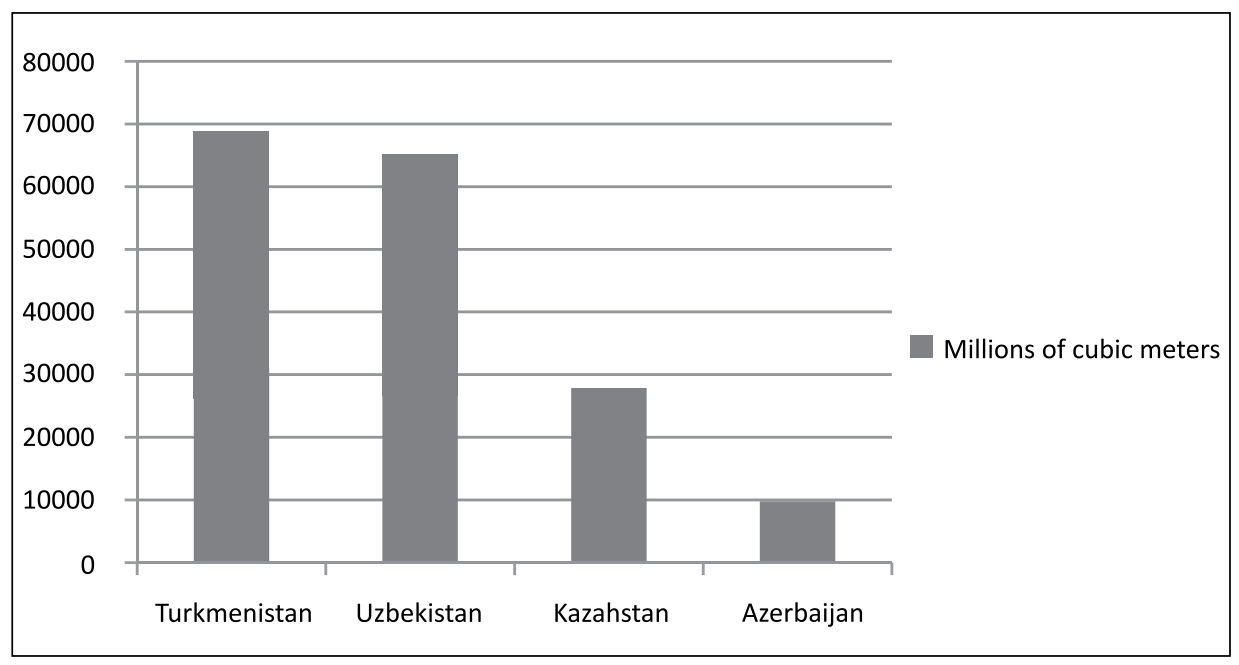

Fig. 4 Natural gas production of Central Asia and Caspian Sea region countries with significant production, 2009 Sl. 4. Proizvodnja prirodnog plina u državama Središnje Azije i regije Kaspijskogjezera koje imaju značajniju proizvodnju, 2009., u milijunima kubičnih metara 
(geoeconomic control over resources, through exploitation concessions and dominance over transport infrastructure) could possibly gain an advantage that no other great power could match. The change of the president, after the death of Niyazov, who established a dictatorship and life-term presidency, did not change the regime nor improve the state of democracy and human rights. But the USA, completely contrary to its rhetoric, does not care, as long as gas and oil are exported. Russia and China care even less about the internal affairs of Central Asian countries, as long as there are no significant changes in their foreign policy orientation.

Producing 68880 million cubic meters of natural gas, Turkmenistan ranked $13^{\text {th }}$ in the World, and Uzbekistan ranked 14th producing 65190 millions of cubic meters. Producing 27880 million cubic meters, Kazakhstan ranked $27^{\text {th }}$. Azerbaijan ranked 42nd, producing 9770 millions of cubic meters. For comparison, Russia ranked $1^{\text {st }}$ in the World, producing 654000 millions of cubic meters, and Croatia ranked 53 ${ }^{\text {rd }}$, producing 2892 million cubic meters of natural gas in 2009. The total natural gas production of the World in 2009 was 3021000 cubic meters.

Russia has an almost complete monopoly on gas exports from Turkmenistan and considers any interference in gas exports a direct threat. The planned pipeline is a major gain for Russia and represents a major breakthrough in energy strategy for Central Asia that is oriented towards keeping involvement of Russia in gas exports as high as possible, creating a gas cartel and practically a monopoly over control of gas exports to Europe ${ }^{7}$. The gas cartel, called the Gas Exporting Countries Forum, comprised of 16 members, was formalized in Moscow, at the end of 2008. Russia was to be the most powerful member. The Central Asian countries of Kazakhstan and Turkmenistan joined the gas cartel. The Russo-Ukrainian gas "war" in January 2009, lasting about 20 days, started over the Ukrainian refusal to pay higher, market gas prices. It led to the Russian closing of the gas pipeline to Ukraine and the rest of Europe. Central and South East European countries were most affected, since some of them are almost completely dependent on gas from Russia. Ukraine was left with no choice but to agree to the Russian terms, and Europe was able only to call on both sides to find an agreement. The key for Russian energy dominance over Europe is not just control of its own gas supply, but also the control over gas supplies from Kazakhstan and Turkmenistan, which have to pass through Russian pipelines to reach the European markets. Russian Gazprom remains the undisputed leader on the gas market in Central Asia, and has a position that is almost monopolistic. Considering the rising importance of gas, as the "oil of the $21^{\text {st }}$ century", it is understandable that the USA has begun playing the strategic game in the Caspian Sea region and Central Asia. American gas and oil companies are also welcome in Turkmenistan and Kazakhstan, and are invited to explore the possible off-shore oil and gas fields in the Caspian Sea.

Russia also managed to gain some strategic advantage in Kyrgyzstan. Prior to 2009, the USA and Russia both had military bases in Kyrgyzstan. Among the countries of Central Asia, Kyrgyzstan has the least geostrategic and geopolitical relevance. It is a mountainous country, is poor and does not possess significant energy resources. It is, however, important as a transit corridor to China, although more convenient transit routes are established through Kazakhstan. However, Russian success and, at the same time, a blow to US interests and strategy in the region of Central Asia, happened at the beginning of 2009. The government 
of Kyrgyzstan decided to deny the US and NATO troops the use of Manas air base, a key point for strategic air-lift and supply of the US troops in Afghanistan and the most important Western military base in Central Asia. Before making this decision, Kyrgyzstan received huge economic benefits from Russia, which also wants to establish a new base in Kyrgyzstan. The location for a new contingent of Russia's increasing military presence would be an old Soviet military base in the outskirts of the Kyrgyz "southern capital", Osh, situated in the volatile Ferghana Valley and bordering Uzbekistan, Tajikistan and China. The successes of Russia in Uzbekistan and Kyrgyzstan, and its improved relations and ties with Turkmenistan and Kazakhstan, are signals that the US influence is being successfully contained.

In addition to its recent geopolitical gains in Central Asia, Russia managed to achieve a strategic gain in the so-called "near neighborhood states". Russia and six countries (Armenia, Belarus, Kazakhstan, Kyrgyzstan, Tajikistan and Uzbekistan), member-states of Collective Security Treaty Organization (CSTO), decided to found their joined response force, called Collective Operational Response Forces $(C O R F)$, to boost their security and fight against common security threats. In June 2009, the leaders of the CSTO countries met in Moscow and signed an agreement on the creation of the Collective Operational Response Forces ${ }^{8}$. This response force looks like a counterweight to the NATO Response Force, and it is significant that countries that participate in this response force have much closer ties with Russia than with NATO. Four of the seven countries that participate in this response force are Central Asian countries. This is a fact that indicates rising Russian influence in the region, and the decisiveness to limit and eventually to exclude US influence from Central Asia in the future. The exclusion of China from this security initiative also shows how the Russo-Chinese alliance has a very limited reach, by its volume and time frame. It will last only until the US influence is powerful enough to pose a threat to both Russian and Chinese influence.

\section{THE RISING INFLUENCE OF CHINA IN CENTRAL ASIA}

Besides the USA and Russia, China also started to raise its influence in Central Asia. Back in September 1997, China reached a provisional agreement with Kazakhstan that would involve construction of a 3,000 km pipeline, linking energy fields in Kazakhstan with Xinjiang. But the deal also had a political dimension. China desired closer relations with Kazakhstan in order to increase its influence in Central Asia and to develop its energy security (Yazdani, 2006). The Kazakhstan-China pipeline was built in the meantime, and serves as a key link of the Caspian oil fields in Kazakhstan with the thirsty Chinese oil market, and it is independent from Russian or US influence, since China and Kazakhstan share a border, so the pipeline crosses through only their territories.

The role of China, regarding its quest for control over oil and gas fields and transport infrastructure in Central Asia, must not be underrated. China's presence in Central Asia is growing. It has signed an agreement on import of natural gas from Turkmenistan that will become effective in 2009. But the planned building of a gas pipeline that would transport gas from Turkmenistan and Kazakhstan to Russia and Europe would jeopardize the ChinaTurkmenistan gas agreement, since Turkmenistan does not have enough production capacity to satisfy the needs of the thirsty European and Chinese gas markets. Turkmenistan would 
have to double its gas production to satisfy the needs of Europe and China, and there is also a possibility of building a gas pipeline across Afghanistan to Pakistan and India. At present, it is totally impossible to satisfy these needs. China will also continue to give economic aid, and to invest into Uzbekistan.

Its influence is continuing and increasing especially through the Shanghai Cooperation Organization (SCO), as a means to accommodate Chinese and Russian interests, a strategic partnership for Central Asia. Although China and Russia both have an interest in reducing American military power and influence in Central Asia, each country has its own distinct agenda. Russia hopes to utilize the SCO to buttress its monopolistic power in gas transit, and, to a lesser degree, oil transit, in Eurasia. China would like to structure the SCO as a facilitator of regional trade and investment with Beijing as the dominant player. The USA perceives the SCO as an obstacle to its interests, and the role of the SCO is primarily perceived as a geopolitical hedge against the rising influence of the USA. The application of the USA, in 2005, to join the SCO, was rejected. A fact that definitely should not be forgotten is that China has direct territorial contact with Central Asia. The pipeline was built from Kazakhstan to China, without any contact with Russian territory. So China is obviously capable of building infrastructure that would transport oil and gas from Central Asia.

\section{THE FUTURE OF CENTRAL ASIA AND THE CASPIAN SEA REGION: A LONG-TERM STRATEGIC RIVALRY?}

Central Asia is too big and too remote to be controlled from one power centre (in the power relations that existed after the collapse of the Soviet Union and the power vacuum that followed it), and especially from a centre far outside the region. The great powers (the USA, Russia and China) want to expand their influence as much as they possibly can. Power centers within the region are too weak to counter the influences from outside it. So, conditions for a long-term strategic rivalry - i.e., the overlapping of rival strategic interests of the great powers, the region's inability to counter these interests and remain as independent as possible, as well as the main reason for strategic rivalry - consist in energy resources that belong among the richest in the world.

The USA will continue to promote its economic interests, so it will try to gain control over as much of the energy resources as possible, and prevent, as much as possible, the flow of energy into China. Although the cooperation between Russia and China is growing, Russia is opposed to the growing strategic role of China in Central Asia. Partnership between these two great powers is a partnership of common interest aimed against the influence of the USA in the region, and not a partnership with common goals. It is an ambivalent partnership, a partnership of balancing against the rising influence of the USA. If the USA were to decide to reduce its interest and influence, this ambivalent partnership would not be a partnership of rivals against a common, more powerful rival, but would again become "normal" rivalry.

One of the options for the US policy in the future is playing the waiting game, since the Russian abilities in keeping the countries that are exporting energy from Central Asia dependent on its oil and gas transport infrastructure are not unlimited. The USA will 
probably keep its military bases in Central Asia as long as they can, in order to play the new Great Game successfully. The US' geostrategy will continue to try to weaken the regimes in the countries that are close with Russia, but it will carefully look to prevent conflicts.

Russia is improving and "tightening" relations with the countries on its borders and all the CIS member-states. In the brief confrontation with Georgia in the summer of 2008, over South Ossetia and Abkhazia, Russia showed that it is capable and willing to "draw the line" where the Western influence in the Caucasus must terminate. In the Caspian Sea region, the Caucasus and especially Central Asia, Russia is reestablishing its strong influence, and continuously maintaining (Belarus, Moldova) and reestablishing (Ukraine) its influence in Eastern Europe and the Balkans (Serbia). However, the US gains in the Caucasus region remain important.

China's economic influence in the Central Asian countries is rising rapidly. China's economic influence is rising in Russia, and it is opening the way to other influences. The US-China rivalry will also influence the future of Central Asia. Notwithstanding US global influence and capabilities, in the struggle for influence in Central Asia, China is a player that borders the region, and the USA, although it has established military bases, is a player from far outside the region.

\section{CONCLUSIONS}

The domino theories are predicting various scenarios of instability and possible conflicts in Central Asia. Besides being an object of strategic rivalry (the geostrategic and geoeconomic importance of the region as a reason for the great powers' struggle for influence and control over energy resources), other security challenges to the regional security of Central Asia exist: economic difficulties, widespread poverty and corruption, almost complete lack of democracy and human rights, environment pollution and degradation, borders that are objects of dispute, a mixture of different ethnic groups and nations, and the rise of radical Islam. However, the region remains relatively stable. Rival strategies that are implemented in the region of Central Asia have the main goal of controlling oil and gas production, and transport and export to the world markets. The USA is trying to gain influence in the region. The global strategy of the USA (in which Central Asia plays the role of an important region) is confronted by Russian and Chinese strategies, which have similar goals: to keep US influence out of the region and to increase their own influence. Russia and China will struggle for their part of control over the energy resources of Central Asia in the future, and Russia will have problems in its struggle with China's economic power, which generates political power that can no longer be completely contained, since it is already present in the region. But when it comes to the struggle with the USA over the control of Central Asia, Russia and China continue to cooperate and maybe even improve and deepen their relations, as well as relations with the countries of the region. This struggle for influence represents a logical triangular strategic game, in which two weaker sides take common ground against the stronger power, by finding compromise over their own differences and satisfying an acceptable level of their interests. Their common interest in 
the future would be to contain American influence in Central Asia as much as possible, without generating new instabilities and serious crisis situations. Central Asia can expect the rival geostrategies to confront each other in the future, on its territory. Open conflict is not probable, but the struggle for influence is happening and will continue in the future.

The combination of rival strategic and economic interests mean that the region will be divided between the spheres of influence of the great powers, which will struggle to keep and to expand the territorial reach and the degree of their control. The perception of a geostrategic struggle for influence in the region between the outside powers as a zerosum game means that any weakening of their own influence means strengthening of a rival, or rivals. Since the Central Asian countries are too weak to contain these influences from outside the region, they are trying to balance between them, at the same time bandwagoning with the influence they find least threatening to themselves, and to the region as a whole. So the new Great Game consequently has its stage and the preconditions for evolvement. Regimes in the region are using rival interests and influence to keep the status quo, since it is the best guarantee of their survival. Any notion of democratization of these countries can come only from the West. If it does, it will bring the regimes of Central Asian countries even closer to Russia and China.

\section{NOTES}

${ }^{1}$ http://en.wikipedia.org/wiki/The_Great_Game

2 Mackinder, H. J., The Geographical Pivot of History, The Geographical Journal, vol. 24, no. 4, 1904, p. 435. Available at: http://www.exploringgeopolitics.org/index.html

3 The legal confusion over the definition of the Caspian Sea's status has not yet been resolved. However, some agreements have been made. But the situation shows the inability to obtain agreement by the five riparian states - Russia, Kazakhstan, Azerbaijan, Turkmenistan and Iran. Until the breakup of the Soviet Union, the Caspian Sea was divided between the Soviet Union and Iran. The real problem is in the difference of opinion between the states that are now independent, so it is a question of succession. The five states have grouped into two groups with opposed positions concerning the status of Caspian Sea. Russia, Iran and Turkmenistan have taken the position that the status of the Caspian is unique. The decision on division of the sea demands a completely new approach to be decided by the Caspian states themselves. Russia champions the concept of an 'enclosed body of water' with a 20-mile strip of territorial waters plus an additional 20-mile exclusive economic zone leading to common ownership of the central area of the Caspian by all the riparian states and subject to agreement by all states.

Kazakhstan has taken the position that Exclusive Economic Zones should be formed by a central line equidistant from points on the coastline. Azerbaijan has two positions: the Caspian Sea should be treated either as 'Border lake' with sectors formed by central median line and internal boundaries, which correspond to the international borders of the Caspian states, or the 'Open sea' concept should be applied, with a 12-mile territorial waters zone and exclusive economic zones not exceeding 200 miles, in agreement with the central line principle. Kazakhstan and Azerbaijan are basically allies in this issue of Caspian Sea status definition.

See:

Blandy, C. W., 1998: The Caucasus Region and Caspian Basin: Change, Complication and Challenge, Report S36, Conflict Studies Research Centre, London, www.da.mod.uk/colleges/arag/document-listings/caucasus/ S36.pdf

Micklin, P., 2000: Managing Water in Central Asia, Royal Institute of International Affairs, Chatham House, London 
${ }^{4}$ In a regional security complex theory, the position of Afghanistan is perceived as the position of an insulator, a state between the two or more regional security complexes. By their nature, insulators are passive in international relations. They divide regional security complexes. Insulators usually look both ways, but they are unable to link the two security complexes. In the case of Afghanistan, this security complexes/sub I complexes are: the Middle East/Northern Africa regional security complex (Gulf sub-complex), the Post-Soviet Space regional security complex (Central Asian sub-complex) and the South Asia regional security complex.

${ }^{5}$ http://www.globalsecurity.org/military/world/int/csto.htm

${ }^{6}$ According to the Corruption Perception Index (CPI) report, published by the Transparency International Organization for 2009, results for Central Asian states were totally disappointing. On the global level, Kazakhstan was in the 120th place on the country rank list. Tajikistan was ranked 158th, Kyrgyzstan 162nd and Turkmenistan $168 \mathrm{th}$. Since the first rank means that country is least corrupted, these countries ranked among the most corrupt countries in the World. Uzbekistan was one of the seven most corrupt countries in the World, according to this survey. Out of 180 countries in which the survey was done, Uzbekistan was ranked in the 174th place.

Reference: http://www.transparency.org/policy_research/surveys_indices/cpi/2009

${ }^{7}$ Besides having control over the energy flow from Central Asia to Europe, Russia also has a large business interest and profit, because it pays US $₫ 100$ for 1000 cubic meters of gas to Turkmenistan, and sells that same gas to Europe at a minimum of US\$ 250 per 1000 cubic meters. However, new contracts that Russia signed with Ukraine at the beginning of 2009 set the price of gas at US\$350 for 1000 cubic meters, from the previous US \$ 180. The doubling of the gas-price showed that the statement of Russian Prime Minister Putin, given at the founding summit of the gas cartel in Moscow, that "the period of cheap gas is over", was serious and realistic. Russian monopoly over the gas transit routes from Central Asia and the Caspian Sea region is one of the most important cornerstones of Russian dominance in gas supplies to Europe, together with its own huge gas reserves.

See: http://www.europeanenergyforum.eu/archives/points-of-reference/gas-politics-economics-r-d-etc/gasexporting-states-agree-qatar-based-gas-opec

${ }^{8}$ http:// www.nps.edu/Programs/CCS/Docs/Central_Asia/Article_July09.pdf

\section{REFERENCES}

Aydin, M., 1999: Regional Security Issues and Conflicts in the Caucasus and the Caspian Regions, in: Krause, J., Spillman, K. (eds.): International Security Challenges in a Changing World, Center for Security Studies and Conflict Research, Zurich

Bakshi J., 2005: Russia and Uzbekistan Sign “Treaty of Alliance Relations”, Strategic comment, Institute for Defence Studies \& Analyses, New Delhi,

Blandy, C. W., 1998: The Caucasus Region and Caspian Basin: Change, Complication and Challenge, Report S36, Conflict Studies Research Centre, London

Bronson, R., 1998: “NATO’s Expanding Presence in the Caucasus and Central Asia”, in Blank, S. J. (ed.): “NATO after Enlargement: New Challenges, New Missions, New Forces”, Strategic Studies Institute, US Army War College, Carlisle Barracks, Pennsylvania

Brzezinski, Z., 1997a: A Geostrategy for Eurasia, Foreign Affairs, vol. 76, no. 5, p. 50-64

Brzezinski, Z., 1997b: The Grand Chessboard: American Primacy and its Geostrategic Imperatives, Basic Books, New York

Buzan, B., Waever, O., 2003: Regions and Powers. The Structure of International Security, Cambridge University Press, Cambridge

De Blij, H. J., Muller, P. O., 2004: Geography: Realms, Regions, and Concepts, Wiley \& Sons, New York

Engdahl, F. W., 2004: A Century of War. Anglo-American Oil Politics and the New World Order, Vancouver 
Engdahl, F. W., 2007: Armageddon: The Hidden Agenda of Washington Geopolitics, Vancouver

Frederick Starr, S., 2005: A Partnership for Central Asia, Foreign Affairs, vol. 84, no. 4, p. 164-179

Fuller, G. E., 1994: The New Geopolitical Order, in: Banuazizi, A., Weiner, M. (eds.), The New Geopolitics of Central Asia and Its Borderlands, Indiana University Press, Indianapolis

Hale, H., 1994: Islam, State-building and Uzbekistan Foreign Policy, in: Banuazizi, A., Weiner, M. (eds.): The New Geopolitics of Central Asia and Its Borderlands, Indiana University Press, Indianapolis

Johnson, C., 2004: The Sorrows of Empire: Militarism, Secrecy, and the End of the Republic, Metropolitan Books, New York

Jones Luong, P., Weinthal, E., 2002: New Friends, New Fears in Central Asia, Foreign Affairs, vol. 81, no. 2, p. 61-70

Kalicki, J. H., 2001: Caspian Energy at the Crossroads, Foreign Affairs, vol. 80, no. 5, p. 120-134

Lloyd, S. J., 2000: Land-locked Central Asia: Implications for the Future, in: Hodder, D., Lloyd, S., Mc Lachlan, K. (eds.): Land-Locked States of Africa and Asia, Frank Cass Publishing, London, p. 97-133

Mc Lachlan, K., 2000: Afghanistan: the Geopolitics of a Buffer State, in: Hodder, D., Lloyd, S., Mc Lachlan, K. (eds.): Land-Locked States of Africa and Asia, Frank Cass Publishing, London, p. 82-96

Micklin, P., 2000: Managing Water in Central Asia, Royal Institute of International Affairs, Chatham House, London

Nanay, J., 2005: Russia and the Caspian Region, in: Kalicki, J. H., Goldwyn, D. L. (eds.): Energy and Security: Toward a New Foreign Policy Strategy, Washington DC: Woodrow Wilson Center Press

O’Lear, S., 2004: Resources and Conflict in the Caspian Sea, Journal of Geopolitics, vol. 9, no. 1, p. 161-186

Savas, B., 2008: The Relationship between Population and Economic Growth: Empirical Evidence for the Central Asian Economies, Journal of Central Asian and Caucasian Studies, vol. 3, no. 6, p. 161-183

Seiple, C., 2004: Heartland Geopolitics and the Case of Uzbekistan, E-note, Foreign Policy Research Institute, http://www.fpri.org/enotes/20040125.seiple.mackinderuzbekistan.html

Sloan, G., 1999: Sir Halford J. Mackinder: The Heartland Theory Then and Now, Journal of Strategic Studies, vol. 22 , br. $2-3$, p. $15-36$

Singh Roy, M., 2007: The Caspian Pipeline Deal and Russia's Energy Strategy in Central Asia, Strategic Comment, Institute for Defence Studies and Analyses, New Delhi

Yazdani, E., 2006: Competition over the Caspian Oil Routes: Oilers and Gamers Perspective, Alternatives-Turkish Journal Of International Relations, vol. 5, no. 1-2, p. 51-64

\section{SOURCES}

http://en.wikipedia.org/wiki/The_Great_Game

http://www.exploringgeopolitics.org/index.html

http://www.guuam.org/general/browse.html

http://www.transparency.org/policy_research/surveys_indices/cpi/2009

http://www.nps.edu/Programs/CCS/Docs/Central_Asia/Article_July09.pdf

http://www.globalsecurity.org/military/world/int/csto.htm

http://www.gfmag.com/gdp-data-country-reports.html

http://www.europeanenergyforum.eu/archives/points-of-reference/gas-politics-economics-r-d-etc/gas-exportingstates-agree-qatar-based-gas-opec 


\title{
SAŽETAK
}

\section{Nova velika igra: suprotstavljenost geostrategija i geoekonomija u Središnjoj Aziji}

\author{
Petar Kurečić
}

Svrha rada jest istraživanje suprotstavljenosti različitih geostrategija i geoekonomija u Središnjoj Aziji i regiji Kaspijskog jezera. Središnja Azija, kao prostor u centru velike euroazijske kopnene mase, vrlo udaljen i odvojen od mora reljefnim barijerama, već više od stotinu godina pobuđuje zanimanje geostratega i geopolitičara. Interes za taj prostor iskazao je i veliki britanski geostrateg H. J. Mackinder, koji ga je svrstao u svoj Stožer, a poslije i u Heartland, kao geostrateški ključan dio svijeta, čijom se kontrolom ostvaruje svjetska moć. Kao prostor koji je pripadao Ruskom Carstvu Središnja Azija imala je važnost i kao frontier prema Britanskoj Indiji, te se gotovo stotinu godina (od 1813. do 1907.) na njenim južnim granicama vodila „velika igra”, strateško nadmetanje dvaju carstava koja su bila zabrinuta hoće li suparnik odlučiti proširiti svoj utjecaj nad prostorom koji su kontrolirala. Ta ,velika igra” nikad nije prerasla u sukob.

U radu je postavljena osnovna teza da se u navedenom prostoru ponovno događa geostrateško nadmetanje, koje ovog puta ima i izrazite geoekonomske aspekte te podsjeća na nadmetanje s kraja 19. i početka 20. stoljeća, koje je nazvano, ,velika igra”. Teza se dokazuje kroz iznošenje argumenata da postoje značajke u geostrateškom nadmetanju koje bi ga mogle kvalificirati kao novu „veliku igru”. Kroz analizu sadržaja relevantne literature o geostrateškim i geoekonomskim značajkama Središnje Azije i regije Kaspijskog jezera, pokušalo se prikazati kompleksnost geostrateških i geoekonomskih odnosa na tom velikom i strateški vrlo važnom prostoru. Također, komparativnom analizom istraživane su strategije glavnih zainteresiranih sila koje se bore za utjecaj u Središnjoj Aziji. Naime nakon stoljeća ruske te potom sovjetske dominacije, raspadom SSSR-a Središnja Azija postala je regijom s pet neovisnih država. I na Kaspijskom jezeru, koje omeđuje Središnju Aziju sa zapada, danas participira pet država, a ne samo dvije. Ruski je utjecaj u devedesetim godinama oslabio, ali se postupno vratio. No pojavili su se suparnici ruskom utjecaju, a njihov utjecaj sve više jača. SAD, Europa, NR Kina te NATO, kao savez SAD-a i Europe, zauzeli su svoje pozicije u natjecanju za zalihe nafte i plina iz Središnje Azije i Kaspijskog jezera, a SAD dominira u toj ,,igri”.

Osnovni razlog za istraživanje odnosa u regiji njena je strateška važnost, posebno kad su posrijedi iznimno velike zalihe nafte i plina, koje ju svrstavaju među najvažnije dijelove svijeta uopće, ali istodobno predstavljaju ugrozu regionalnoj sigurnosti, s obzirom na suprotstavljene interese velikih sila vezane uz Središnju Aziju. Geostrateška važnost Središnje Azije čini je neizostavnim predmetom geostrateških i geoekonomskih istraživanja. Teorije domina predviđaju različite scenarije nestabilnosti i mogućih sukoba u Središnjoj Aziji. Osim što je kao regija predmet suparništva velikih sila i time podložna nestabilnostima i mogućim sukobima, sigurnosti Središnje Azije prijete i ostali sigurnosni izazovi: ekonomske poteškoće, raširenost siromaštva i korupcije, gotovo potpuna odsutnost demokracije i poštovanja ljudskih prava, zagađenje okoliša i prekomjerno iskorištavanje resursa, granice koje su predmet sporova među državama, etnička izmiješanost različitih naroda koji čine manjine u državama susjednim onoj koju smatraju svojom dotadašnjom postojbinom te radikalne islamističke tendencije i skupine koje ih zagovaraju. No bez obzira na sve te ugroze sigurnosti, regija zasad ostaje relativno stabilna. Glavni razlog tome jest činjenica što sve zainteresirane strane ne žele radikalnu promjenu postojećeg stanja i svjesne su da bi bilo kakav sukob ugrozio širu regionalnu sigurnost te doveo do prekida izvoza nafte i plina iz regije. 
Glavni je cilj suprotstavljenih strategija koje se primjenjuju na Središnju Aziju kontrola proizvodnje, transporta te izvoza nafte i plina. Globalna geostrategija SAD-a, u kojoj Središnja Azija zauzima mjesto jedne od najvažnijih regija koje treba kontrolirati, ima suparnike u ruskoj i kineskoj strategiji, čiji su ciljevi slični: držati utjecaj SAD-a što je moguće više izvan regije i jačati vlastiti utjecaj u regiji. Cilj američke strategije za Središnju Aziju i regiju Kaspijskog jezera jest izgradnja što većeg broja naftovoda i plinovoda koji će zaobilaziti Rusiju te uspostava bliskih režima na ruskim granicama. Rusija želi očuvati što je moguće više utjecaja koji je imala u sovjetskom razdoblju te zadržati što veću razinu ekskluzivnosti u transportu nafte i plina. Zato i novu infrastrukturu želi usmjerivati tako da prolazi njenim teritorijem. Rusija i NR Kina međusobno će se boriti za što veći dio utjecaja nad zalihama nafte i plina u Središnjoj Aziji, pri čemu će Rusiji stvarati poteškoće ekonomska moć NR Kine, koja sve više generira politički utjecaj, koji više nije moguće potpuno suzbiti jer je već prisutan u regiji. No kad je posrijedi borba sa SAD-om oko kontrole u Središnjoj Aziji, Rusija i NR Kina nastavit će surađivati te će vjerojatno poboljšati i produbiti svoje odnose te one s državama u regiji. Prisutnost SAD-a u Iraku, prisutnost SAD-a i NATO-a u Afganistanu, vojne baze SAD-a u Kazahstanu i Kirgistanu, značajna ruska prisutnost u Uzbekistanu i Tadžikistanu, vojne baze u Kazahstanu i Kirgistanu, rastući utjecaj Kine, blizina Irana regiji te brojni vojni i gospodarski sporazumi i savezništva pokazuju da je Središnja Azija predmet suparništva velikih sila. U budućnosti možemo očekivati ravnotežu snaga sa stalnim pomacima, nestabilnost i borbu za kontrolu nad izvorima energije. Nova je „velika igra” počela, i sada je u ranoj fazi.

Petar Kurečić, Ph. D.

University College of International Relations and Diplomacy

Ilica 242, Zagreb, Croatia

e-mail: petar.kurecic@diplomacija.hr 